\title{
"WARS OF NATIONAL LIBERATION" AND THE MODERN LAW OF NATIONS-THE SOVIET THESIS ${ }^{\dagger}$
}

\author{
George Ginsburgs*
}

\section{INTRODUCTION}

What exactly do Soviet spokesmen understand by "wars of national liberation?" The answer would seem simple enough and yet is not, for no authoritative definition of the concept has ever been offered by its Soviet advocates. Rather, over the years its official uses have varied, and the record shows that, in practice, three broad categories of cases can be distinguished in which the formula has been applied to situations involving armed hostilities: "Wars of liberation, waged to defend the people from foreign attack and from attempts to enslave them; or to liberate the people from capitalist slavery; or, lastly, to liberate colonies and dependent countries from the yoke of imperialism." "Though the conflicts so described have many features in common, to be sure, technically they stand far apart.

For the purposes of this paper, attention will be focused on the last type of contingency, namely, "wars ... to liberate colonies and dependent countries from the yoke of imperialism," since that is the meaning normally attributed today in the U.S.S.R., as well as outside that country, to the expression which represents the object of our analysis. As for the other two kinds of "wars of liberation," they will be considered to the extent alone that they prove germane to the topic on which we propose to concentrate, and only in so far as one can extrapolate from what has been said concerning the rules of state behavior valid in the context of the subject to which we intend specially to address ourselves here. ${ }^{2}$

Having thus pinpointed where our principal interest lies, we can now proceed to dissect the current Soviet thesis on modern "wars of national liberation," taking

T This paper is the latest in a series of studies by the author on various aspects of the Soviet attitude, in theory and practice, toward the laws of war. For the earlier publications, see Ginsburgs, $A$ Case Study in the Soviet Use of International Law: Eastern Poland in 1939, 52 AM. J. INT'L L. 69-84 (1958); The Soviet Union as a Neutral, 1939-1941, 10 Soviet STudies 12-35 (1958); The Soviet Union, Neutrality and Collective Security, 1945-1959, 2 Osteuropa-Recht 77-98 (1959); Laws of War and War Crimes on the Russian Front During World War II: The Soviet View, II Soviet Studies 253-85 (1960); Neutrality and Neutralism and the Tactics of Soviet Diplomacy, 19 AMERICan Slavic and EAst EUropean REview 531-6o (1960); The Soviet Union, the Neutrals and International Law in World War II, II INr'L \& CoMP. L.Q. I7I-230 (I962). All translations from the Russian into the English language, unless otherwise indicated, are the author's.

* Assistant Professor of Political Science, University of Iowa.

${ }^{2}$ History of the Communist Party of the Soviet Union (Bolsheviks), Short Course 167-68 (1939) (edited by a Commission of the Central Committee of the C.P.S.U.(B.)).

2 It must be remembered, however, that the classification of conflicts as one or another type of "just" war is not subject to any hard and fast rule. A conflict may well start out as one kind of "just" war and then turn into another, or the same conflict may at one and the same time fall into two categories. The Korean war, for instance, is usually described in Communist literature as a revolutionary civil war against the South Korean capitalists and a war of national-liberation from "U.S. imperialism." 
it point by point and discussing and evaluating its constitutive elements as we go along.

I

The Legal Nature of Colonial Wars

To begin with, in accordance with a long-standing tradition, conflicts generically identified as colonial wars (regardless of the variety of names associated with these incidents in popular history) have been viewed in most quarters as a species of domestic strife, and hence as standing beyond the purview of international law. Until recently, nations which were thought suitable to be brought under colonial rule and atttempted to fight against the fate in store for them or which, once reduced to that subject status, tried to overthrow their bondage and regain their freedom, saw themselves denied the protection of international law. The standard rationale was, of course, that the latter extended solely to the relations between so-called civilized states that formed a select club which excluded all communities that the in-group chose to classify as backward, barbarian, savage, inferior, or the like.

The Kremlin, on the other hand, has always maintained that these military campaigns to secure fresh colonial possessions or to hold on to those already acquired in the face of a native challenge to such alien exploitation must properly be treated as international wars in every sense. Rejecting any discriminatory differentiation among the world's organized political entities on the old grounds of race, religion, level of social or economic development, and so forth, Soviet legal doctrine has instead defended throughout the notion of their perfect juridical parity. By that token, it has refused all along, ex principio, to accept any excuse for depriving any duly functioning national community of its equal rights under world law.

And, it should be further noted, in Soviet theory this proposition obtains not only for those communities which can validly claim to form effectively self-ruling statelike organisms, no matter how rudimentary their governmental system, but also for such national movements as are still merely in the process of struggling to create their own independent polity. Interestingly enough, so as to be able to propound this thesis, the Soviets have had to broaden somewhat the scope of their basic definition of subjects of international law (otherwise very restrictively understood), in order to accommodate this particular doctrinal element.

Indeed, whereas today the trend in most of the world moves more and more in the direction of a qualified recognition that international law no longer applies to states alone, but encompasses a variety of international personalities other than states as well, including, possibly, individuals, the Soviets have to date adamantly opposed most aspects of such an expansion of international law. Their jurists, with rare exceptions, continue to cling to a very conservative conception of what can constitute a subject of international law. The single, marked concession in this respect, as already mentioned, is in the case of "peoples fighting for national 
liberation." Here, Soviet jurisprudence does make a certain allowance, acknowl. edging that in effect

there arises the question of the possibility of ascribing nations to the class of subjects of international law. Practically, such a question arises after a nation has acquired the traits of a state, having formed some organ (national committee, etc.) which in the carly stages then acts in the name of the nation. Given the existence of such organs, a nation fighting for its independence and which is in the phase of inaugurating its own state, as a rule, acts as a subject of international law. ${ }^{3}$

The exception still represents but a minimal departure from the basic principle in that the formal emergence of the nation on the international arena remains tied to the condition that it show evidence of possessing a quota of state-like attributes, no matter how embryonic their level of development or low their standard of performance.

Another, younger school of thought, however, which has been gaining in popularity lately in Soviet juridical circles, now goes further and proposes to waive even these token requirements. ${ }^{4}$ As its exponents look at the issue, every nation qua cohesive and distinct social unit is inherently seized of the quality of "national

${ }^{3}$ Evgeniev, in F. I. Kozmevnikov (Ed.), Mezhounarodnoe Pravo (International Law) 87 (I957). For others who maintain essentially the same point of view, see D. B. Levin, Osnovnye Pronlemy Sovremennogo Mezhdunarodnogo Prava (Basic Problems of Contemporary International Law) 79 (1958); L. A. Modzhoryan, Subyekty Mezhdunarodnogo Prava (Subjects of International Law) 8 (1958); id., Osnovnye prava $i$ obyazannosti subyektov mezhdunarodnogo prava (Basic Rights and Duties of Subjects of International Law), Sovetsku Ezhegodnik Mezhdunarodnogo Prava 1958, at 280 (r959); F. I. Kozhevnikov, Uchebnoe Posobie po Mezhounarodnomu Publichnomu Pravu (Ocherki) (Public International LaW Textbook (Outline)) 5 I (1947); V. I. Lisovskit, Mezhdunarodnoe Panvo (Intennational Law) 65 (I955); id., Mezhidunarodnoe Pravo (International Law) 69 (2d ed. 196r); S. B. Krylov, in E. A. Korovin (Ed.), Mezhdunarodnoe Pravo (International Law) i58 (I95I); G. I. Tunkin, Osnovy Sovremennogo Mezhounarodnogo Prava (Basic Principles of Contemporany IntenNATIONAL LAW) I7 (1956).

- Tuzmukhamedov, Natsionalno-osvoboditelnaya revolyutsiya $i$ nekotorye voprosy meahdunarodnogo prava (Revolution of National-Liberation and Some Questions of International Lat ), UcheNYe ZaPISKI (Instrtut Mezhdunarodnyrf OtNoshenir), No. Io, Legal Series, at 120-29 (I962); G. B. Starushenko, Printsip Samoopredeleniya Narodov i Natsil vo Vneshnei Politike Sovetskogo (The Principle op Self-Determination of Peoples and Nations in the Foreign Policy of the Soviet States) $143-45$ (1960); Blishchenko, Vazhnyi vopros mezhdunarodnogo prava (An Important Question of International Law), [I960] Sovetskoe Gosudarstvo I Pravo, No. I, at 52 (review of Yu. G. Barsegov, Territoriya $\checkmark$ Mezhdunarodnom Prave (Territory in International Law) (r958); Yu. G. Barsegov, Territoriya $\checkmark$ Mezhounarodnom (Territory in International Law) 68-I55 (I958). Recently, Korovin, too, has started echoing this theme. See Korovin, Suverenitet $i$ mir (Sovereignty and Peace), 9 MezuduNARODNAYA ZHIZN 9-I8 (I960).

However, most Communist legal authors, it should be noted, continue to treat "national sovereignty" not as an independent concept but as synonymous with "the right to national self-determination." Thus, see Modzhoryan, Borba demokraticheskogo lagerya za natsionalnuyu nezavisimost i natsionalnyi suverenitet (The Struggle of the Democratic Camp for National Independence and National Sovereignty), [1953] Sovetskoe Gosudarstvo I Pravo, No. 1 , at 52, 56; Ponyatic suvereniteta (The Concept of Sovereignty), id. [1955], No. I, at 68, 70; Evgeniev, Pravo subyektnosti, suverenitet i neumeshatelstuo (Legal Personality, Sovereignty, and Non-Intervention), id. [I955], No. 2, at 75; C. Berezowski, Nekororye Problemy Territorialnogo Verkhovensta (Some Problems of Territorial Sovereignty) 63-67 (translated from the Polish by V. L. Kon, I96r). Earlier, Korovin, too, shared this vicw. See, for example, his Nekotorye osnovnye voprosy sovremennoi teorii mezhdunarodnogo prava (Some Basise Questions in the Contemporary Theory of International Law), [1954] Soverskoe Gosudarstvo I Pravo, No. 6, at 34,43 . 
sovereignty." This "national sovereignty" is the quintessence of what constitutes a nation, both spiritually and materially; it corresponds to the sum total of those inalienable rights of a given human group which stamp it as a nation. This core element is the source from which flow all the secondary rights that accompany this "national identity"-inter alia, the right to political, economic, and cultural auto-determination. Once possessed of "national sovereignty," a nation can be deprived of it only if the community itself is totally destroyed. Otherwise, a nation always retains this attribute, regardless of its technical juridical status at a particular moment in history. Thus, a community reduced to subject stature, though not politically sovereign, on the plane of "national sovereignty" remains the equal of its independent counterparts, notwithstanding the loss of its facilities for self-government. Its faculties for self-government no nation presumably can lose forever, again short of its physical annihilation.

Every nation, then, by virtue of its natural endowment with "national sovereignty" stands as a full-fledged subject of modern international law. For, so the advocates of this viewpoint say, contemporary state practice openly recognizes the principle of "national sovereignty" as part of the general corpus of international law and, consequently, assures every national entity, in that capacity alone, all the rights and privileges of complete jural personality. Proof positive for the accuracy of the assertion that "a whole series of rights of nations, not yet formally organized as states, are nonetheless recognized by international law" and that "these rights have become international legal norms" is found in the fact that, "for instance, the principle of equality and self-determination is ratified by the Charter of the United Nations Organization (UNO), the rights of nations are protected by the convention of 1948 prohibiting genocide, the Geneva conventions of August I2, I949, the Geneva agreements on Indochina of $1954 \ldots . . .5$

In either case, whether insisting that a nation display a modicum of organizational features associated with statecraft before it can attain international dimensions, or waving aside all technical prerequisites in connection with that process, Soviet jurists are agreed that "a nation struggling for self-liberation" ipso facto satisfies whatever criteria, if any, it must meet to achieve international stature. Hence, it forthwith qualifies as a subject of international law in every sense of the word. Indeed, it is claimed, the great merit of Soviet teaching on the topic of subjects of today's international law and its major contribution to the current doctrine in this sphere lie precisely in its elaboration and defense of this theme, a stand seen as amply vindicated by the present course of world events. In Communist quarters, the verdict on this point is unanimous and its tone uniformly jubilant, for the message it undertakes to convey is that

... the recognition as subjects of international law not only of States, but also of nations struggling for their independence, is an indispensable deduction of the Soviet doctrine of

'Tuzmukhamedov, supra note 4 , at I2I. 
international law which is confirmed by the success of the national-liberation movement of oppressed peoples, above all in Asia and Africa. ${ }^{6}$

While the Soviets have thus found it easy to insist in abstract terms that there now exists a principle of international law prescribing that armed hostilities in colonies and dependent territories be unreservedly classified as international wars, citing rules of positive law in support of this contention has proved more difficult. Moscow's spokesmen have, therefore, mostly rested content with vague general references to the spirit and, less frequently, isolated samples of the letter of the U.N. Charter. True, one can point to the clauses of the Geneva conventions of 1949 enjoining that the usual laws of war be observed in prosecuting civil and colonial wars too. And, as is shown above, Soviet jurists have not overlooked this aperture. Yet, this innovation, which most Soviet sources acclaim (rightly) as belatedly bearing out the U.S.S.R.'s position in this matter and the insertion of which in the agreements they attribute (with no good justification) ${ }^{7}$ solely to Soviet exertions on its behalf at the Conference, ${ }^{8}$ has but a strictly technical connotation. Whatever its origins-and one must give the Soviets due credit for their prolonged efforts to gain universal recognition for the proposition in question-it still represents no more than a humanitarian endeavor to alleviate the sufferings caused by all armed conflicts through maximum application of jural limitations to the exercise of public violence, irrespective of its formal nature. However, to argue from this that colonial struggles have been raised by these conventional rules to the full status of international wars would be analogous to announcing that, since the Geneva conventions of 1949 deal with conditions arising from belligerency, wars are thereby legalized and the explicit stipulations of the United Nations Charter to the contrary expressly overridden. The contention simply does not hold.

Besides the Geneva conventions of I949, Communist legal experts claim to have found material evidence to support their thesis in the Geneva agreements of I954 concerning Indochina. According to this line of reasoning, colonial campaigns and their organic concomitants, wars of national liberation, had always been international wars, but it took the end of the struggle for Indochina to secure formal acceptance of this fact by the "bourgeois" world. In the words of an authoritative Polish lawyer,

\footnotetext{
'Krylov, $K$ obsuzhdeniyu voprosov teorii mezhdunarodnogo prava (Concerning the Discussion of Theories of International Law), [1954] Sovetskoe Gosudarstvo y Pravo, No. 7, at 76 .

'As Pictet, The New Geneva Conventions for the Protection of War Victims, 45 AM. J. INT'L L. ${ }_{4} 69$ (I95I), points out, "the new conventions [signed at Geneva] do not go as far as the Stockholm drafts [of I943], which proposed that the conventions should make specific provision for civil war as well as for war between states." The U.S.S.R. attended the Geneva conference, but not the Stockholm session.

${ }^{8}$ See, e.g., Sharmanazashvili, Kolonialnaya voina-gruboe narushenie mezhdunarodnogo prava (Colonial War-A Serious Violation of International Law), [1957] SoveTsKoe Gosudarstvo I pruvo, No. 10, at 59. See, too, Latyshev, Zhenevskie konventsii 1949g. O zashchite zhertv voiny (The 1949 Geneva Conventions for the Protection of Victims of War), id. [x954] No. 7, at 121-25; Amclin, Mezhdunarodno-pravovaya zashchita uchastnikov grazhdanskikh $i$ natsionalno-osvoboditelnykh voin, Sovetskn Ezhegodnik Mezhdunarodnogo Prava 1958, at 397-406 (1959).
} 
... the Geneva agreements recognized that national-liberation wars, by which peoples realize their right to self-determination, as just wars are from the standpoint of law legitimate wars. Recognizing the international legal character of national-liberation wars, they coincidentally recognized that questions of self-determination cannot be regarded as internal legal processes of the metropolitan country or the empire, that the hands of the colonial powers are not free to pacify and suppress national-liberation movements. ${ }^{9}$

To get around the obvious criticism that, after all, the 1954 Geneva agreements represented no more than an ad hoc arrangement between a limited number of countries to resolve a purely local dilemma, the author further maintains that, in this respect, the documents adduced by him belong to the same category as the sundry Hague conventions on the laws of war, the several Geneva conventions and protocols on the same subject of pre-war and post-war vintage, the Statute of the Nuremberg tribunal, and so forth. In his opinion, all these multilateral treaties, together with the 1954 Geneva documents on Indochina, amount to no more than the end product of a long process of codification, and so merely "confirm certain principles, express customary law in treaty norms, or contain a recognition of earlier practice applied in a concrete case." ${ }^{\text {"10 }}$ Citing the passage in the judgment of the Nuremberg tribunal to the effect that, "indeed, in many cases treaties do no more than express and define for more accurate reference the principles of law already existing,"11 he concludes that "the substantive stipulations of the Geneva agreements must be understood the same way":

The basic principles of the Geneva agreements even before the adoption of these documents represented the accomplishments of progressive humanity, were legal principles which even the most reactionary forces did not deny. Their recognition, however, carries a purely theoretical, declarative character. In the Geneva agreements they acquired concrete real form and content linked to life. ${ }^{12}$

As such, then, he finds the latter totally analogous to the provisions of the Charter of the United Nations and to other like rules that bind even those states which

- M. Lrchs, Zhenevskie Soglasheniya 1954G. ob Indo-Kitae (The I954 Geneva Agreements on Inno-Cuins I89 (tr. from the Polish by E. I. Brainin and K. A. Radvillovich, I956). The same argument is echoed by G. B. Stanushemso, op. cit. supra note 4, at 135; Tuzmukhamedov, Mirnoe sosushchestvovanie i natsionalno-osvoboditelnaya voina (Peaceful Coexistence and National Liberation War), [1963] SoversKoE Gosudatstvo I Pravo, No. 3, at 87, 92-93.

${ }^{10}$ Lachs, op. cit. supra note 9, at 190.

2122 Trial of the Major War Criminals Before the International Military Tribunal, Judgment 464 (I948); 2 Nyurnbergskil Protsess, Sbornik Materialov (The Nürnberg Trial, Collection of Materiazs) 453 (I95I).

Not all Communist lawyers, it should be noted, subseribe to this theory of "codification" in the case of the Statute of the Nüremberg Tribunal, for instance. Thus, Baumgarten, Etatischeskii vaglyad na mezhdunarodnoe pravo (The State-Oriented View of International Law) (tr. from the German by F. A. Kublitskii), in Gosudarstvo i Pravo v Svete Velikogo Oxtyabrya (State and Law in the Light of THE Great Octóer), 82-83 (I958), frankly admits that the Statute is a "law ad hoc, an international criminal law and, what is more, one with retroactive effect," but nevertheless claims that it is good law because "the validity of the criminal law contained in the Statute is based on the fact that in content as well as in form it corresponds to the demands of the overwhelming majority of the peoples of the globe justly to punish those who before and during the Second World War showed themselves to be enemies of the human' race."

${ }^{12}$ Lachs, op. cit. supra note 9, at $19 \mathrm{I}$; id., Mnogostoronnie Dogovory (Multilateral Treaties) sgr (tr. from the Polish by G. F. Kalinkina) ( $\mathrm{r} 96 \mathrm{I}$ ). 
never formally subscribed to them. Hence, he sees them as a general statement of contemporary international law of universal validity.

Ingenious as the argument sounds, it nevertheless fails to convince, for neither in conception, substantive scope, effect, breadth of focus, and interest did the Geneva accords of 1954 come anywhere close to the conventions with which they are thus equated. For that matter, much of what was agreed to just ten years ago is today a dead letter. This, of course, is also true of the Hague and earlier Geneva conventions, but these have been outdistanced by the progress of history and the advance of technology. In any event, no country has as yet refused outright to abide by the basic precepts of these latter treaties, even when seeking to reinterpret or set aside some particular clause, and these treaties still bear the signature, adherence, or oral acceptance of probably every country in the world. As against this, the Indochina accords never transcended the bounds of a circumscribed plurilateral transaction, which remained, as far as the overwhelming majority of the global community was concerned, purely res inter alios acta. Furthermore, as noted before, the solutions proposed in these documents have since for the most part broken down and been tacitly abandoned even as between the original con. tracting partners.

Added to that, it is hard to discern in the contents of the 1954 Geneva agreements any general principles of the order of the fundamental postulates formulated in those other conventions to which they are here pronounced kin; instead, the language of the former retains throughout the flavor of a technical blueprint with a narrowly delimited purpose and raison d'être. And, finally, whereas the older treaties named in this connection, though drafted by a small portion of the earth's nations, were nonetheless expected to attract wider, nowadays world-wide, endorsement, no solid evidence can be found of such practical intent behind the arrangements for bringing back peace to Indochina.

As for "national sovereignty," international law knows of no such concept. At best, it leaves the impression of a meta-juridical Grindnorm of sorts, an "ideal" construction which has no firm roots in the infrastructural pattern of current jurisprudential thought and finds no substantive reflection in its superstructure of positive law rules culled from state practice.

Let us assume, however, for the sake of argument, that colonial wars are international wars in the eyes of modern international law. The next step would logically be to assume that the prescriptions of international law on the proper conduct of war would then apply to these conflicts too. Well, in part they do, since all Soviet commentators insist that the colonial power waging the fight to preserve its ascendency over the dependent territory must be bound by each and every provision of international law pertaining to the modalities of civilized warfare. For that matter, the very object in pleading that colonial wars are international wars is precisely to put those who do so in a position to advance this further claim. But when it comes to drawing the inevitable companion conclusion, namely, that the 
movement struggling for national liberation must equally observe the established norms of international law on how to wage war, there the Soviets suddenly begin temporizing; and all at once their attitude turns thoroughly ambiguous.

Curiously enough, the avenue of escape seized upon so as to avoid ending up in such a spot is one provided by Engels who wrote in 1857 that "in a popular war the means used by the insurgent nation cannot be measured by the commonly recognized rules of regular warfare, nor by any other abstract standard, but by the degree of civilization only attained by that insurgent nation."13

On historical and sociological grounds, then, according to Engels, so-called backward and primitive peoples cannot and should not be held to the observance of the laws of war unilaterally promulgated by the more "civilized" powers and reflecting the values and level of technical development of the more advanced societies. To do so would, in his estimate, be altogether illogical, impracticable, and dishonest. At the same time, Engels asserted, the natural inability of any "insurgent nation" of this type to grasp the meaning of the laws of war in force between the European countries in no way absolved the latter from the obligation to implement the regulations devised by themselves and accurately reflecting their own outlook on what constituted proper behavior in the course of armed hostilities as among enlightened states. As he saw it, simple objective reality dictated that in a given conflict each of the contestants should follow that set of rules regarding the conduct of military operations which best corresponded to its value system and, actually, it could be expected to do no more or act otherwise, as long as it did no less. So, while primitive peoples fought as their tradition demanded of them, civilized nations, he felt, ought, in turn, to prosecute war in conformity with the standards they normally embraced, or a least pretended they embraced and sometimes enforced in their relations with neighboring communities which they tolerated as equals.

The historical and moral element in Engels' argument is irrefutable. The sight of a so-called progressive nation posing as a sine qua non for its own behavior that some tribe it was engaged in pacifying should abide by the modern laws of war or else forgo every claim to be dealt with in accordance with these laws does strike the impartial observer as ludicrous. On the other hand, while one can sympathize with Engels' conclusions and concede their scholarly soundness, it is nevertheless necessary to admit that in practical terms they seem sadly unreal. As an ideal and abstract construction, they stand beyond reproach. But, it is here suggested, in daily life a Gresham's law of sorts operates in the legal sphere as well as in the field of high finance. That is to say, in the confrontation between two unequal systems of legal tradition, it is believed that the inferior one will at first prevail, in the sense that the superior product will come down to the level of the other and compete with it on its own plane, instead of vice versa.

This, unfortunately, appears to be particularly true in warlike situations, where

${ }^{13}$ Engels, Persia and China, N.Y. Daily Tribune, June 5, $\times 857$, reprinted in K. Marx \& F. Engels, On Colonialisar III, II5 (Moscow, n.d.). 
the common denominator regulating the behavior of the combatants is ordinarily the lowest standard discernible in the practice of the opponents. In general, of course, metropolitan troops everywhere do show a marked inclination to behave differently on home territory and overseas or abroad, and even more differently when in a familiar social environment as compared to when they find themselves shipped to a strange location and surrounded by people whom they are conditioned to regard as an inferior form of life. Aside from this factor, however, in the midst of any hostilities there seems to be a natural tendency to treat the enemy just as he treats you and no better. Hence, regardless of academic appeals to historical and economic determinism, it is the pattern set by the more "primitive" party which has almost always obtained, to the near exclusion of the higher standards which the other belligerent ordinarily professes to recognize.

Without being unduly cynical, one may suggest that this has ever been a part of human character and, as the record indicates, contrary opinion has so far proved thoroughly unrealistic, be it that of Engels in his time or that of Communist writers on diplomatic affairs who echo him today. ${ }^{14}$ Sad to say, the temptation to reciprocate with like action must just be too irresistible, all strictures notwithstanding. To demand that international law enjoin the colonial powers to wage war according to the lofty ideals set forth in the latest conventions, while the national liberation movements to all intents and purposes behave as they please because they are not sufficiently mature to grasp the essence of these alien rules, is also to tax credulity. Swinging from one extreme to the other cannot furnish and, indeed, has not furnished a workable answer to a problem already difficult enough as it is. Apologists for unbridled imperialism may have been altogether wrong. But then, current apologists for unbridled anti-imperialism, with the Communists in the forefront wielding pseudo-legal arguments such as the above, are no less so. Both insist on misusing and abusing international law for their own immediate ends, with sorry results every time and in a manner unacceptable to most who think of international law as a constructive, rather than a destructive, instrument in the relations between states.

II

\section{Colonial Wars and the Notion of Aggression}

The drive to gain recognition for the principle of internationalization of colonial wars and wars of national liberation serves yet a further purpose-that of bringing such conflicts within the scope of the notion of aggression. In effect, it must be remembered that the latter concept, as defined in Soviet pronouncements, always applies only to actions lying within the realm of inter-state relations. ${ }^{15}$ By this token, armed conflicts within a state and also between two halves of a

\footnotetext{
14 Meleshko, in Korovin (ED.), op. cit. supra note 3, at 506.

${ }^{16}$ See Yuridicheskit Slovar (Legat Dictionary) I2-15 (1953); P. I. Kudryavtsev (Ed.), I Yuridicheskit Slovar (Legal Dictionarx) r5-19 (2d ed. 1956).
} 
divided country do not fall within the rubric of such use of force as can be qualified as an act of aggression. ${ }^{16}$

If today, as was common practice in the past, the proposition were successfully defended that the ties between a metropolitan power and its dependent territories were regulated by domestic law alone, then whatever conflicts disrupted the association technically could not belong to the category of incidents to which the epithet of aggressive would apply. Yet, the Soviets are and all along have been intensely interested, for reasons that will quickly become apparent, to extend this frame of reference to military hostilities in the colonies as well. By asserting that any struggle between a colonial power and a native independence movement amounts to a formal international war since it represents an armed collision between two distinct entities, each fully acknowledged as a subject of international law in its own right, the Soviets are ultimately able to claim that such a clash is automatically eligible to be judged in the light of whether an aggression has been committed. The next logical step, of course, is to determine who is the aggressor and who the victim and what remedial measures must be taken in an emergency of this sort.

In reality, the Soviets bother little with a detailed assessment of the circumstantial evidence in such instances, for, thanks to a priori reasoning, the answer is immediately forthcoming from them that such outbreaks of violence definitely represent every time a case of aggression, since one party to the contest must be pursuing a colonial policy which has provoked the fighting and the resulting colonial wars stand eo ipso condemned as acts of deliberate aggression. Let us take this one step further and consider what the Soviets postulate as constitutive elements of aggression. The prime determinant ingredient, one may gather from all their statements, is which side stooped to overt use of force first. The party so found guilty of resort to arms is thereby branded an aggressor. ${ }^{17}$ The situation seems simple enough and, on the face of it, the criterion for passing sentence sounds not altogether unreasonable. What makes it thoroughly suspect, however, is the ideological context in which the decision as to who started the shooting is rendered, for here all at once extrinsic and totally subjective standards are seen to intrude on a process originally touted as a strictly objective kind of operation.

In order to illustrate best how this turnabout is consummated, one need but quote from the original sources. Thus, examine, for a moment, this revealing passage from one of Lenin's works, penned in 1915 , in the midst of World War I, in which he wrote:

${ }^{10}$ E.g., speech by A. Ya. Vyshinskii at a meeting of the U.N. Political Committee, Oct. 12, I950, Pravda, Oct. 5, 1950; Tavrov, Prestupnaya voina amerikanskikh imperialistov protiv koreiskogo naroda (The Criminal War of the American Imperialists Against the Korean People), I TRuDY INsTIrUTA Prava ARAdemil NaUr SSSR I00 (I95I).

${ }^{17}$ Cf. K. A. Baginyan, Agressiya-Tyagchaishee Mezhdunarodnoe Prestuplenie, $\mathrm{K}$ Voprosu ob Opredelenil Agressi (I955) (Aggression-A Most Serious International Crime, ON the Question of Definition of Aggression), passim. 
The epoch of 1789 -187i left deep traces and revolutionary memories. Before feudalism, absolutism and alien oppression were overthrown, the development of the proletarian struggle for Socialism was out of the question. When speaking of the legitimacy of "defensive" war in relation to the wars of such an epoch, Socialists always had in mind precisely these objects, which amounted to revolution against medievalism and serfdom. By "defensive" war Socialists always meant a "just" war in this sense (W. Liebknecht once expressed himself precisely in this way). Only in this sense have Socialists regarded, and now regard, wars "for the defence of the fatherland," or "defensive" wars, as legitimate, progressive and just. For example, if tomorrow, Morocco were to declare war on France, India on England, Persia or China on Russia, and so forth, those would be "just," "defensive" wars, irrespective of who attacked first; and every Socialist would sympathize with the victory of the oppressed, dependent, unequal states against the oppressing, slave-owning, predatory "great" powers. ${ }^{18}$

It is indeed significant that the Kremlin's current theses on so-called wars of national liberation should sound as but a faithful echo of this Leninist proposition enunciated almost half a century ago, so that the mere change of a few words would suffice to bring it into full conformity with the official line presently expounded by Moscow on every opportune occasion. On this count, at least, the Soviet ideological record has so far evidenced a remarkable, and rare, continuity in attitudinal patterns.

In fact, lest there remain some doubts whether these views are still held in the U.S.S.R. today, an excerpt from an article published in its leading legal journal forty two years later will put them to rest. It is worth citing at length, for not only does its formulation closely parallel Lenin's original thought, but it also brings the latter up to date to reflect current world conditions, so that, were Lenin dealing with the subject now, one ventures to suggest that he would not have phrased the idea very differently or done so much more eloquently. The relevant paragraph reads as follows:

The national-liberation war of a dependent people against the colonial power will always be a just, defensive war from the political as well as the legal standpoint, independently of who initiated the military action. The whole thing is that in the given instance the fact of initiation of a national-liberation war by a dependent colonial country has no significance for the determination of the aggressor, since the state of dependency and disenfranchisement of the colonial peoples is the result of an imperialist aggression committed earlier, expressing itself in the annexation of these territories. This means that the national-liberation war begun by a dependent, disenfranchised peoplc will represent but a lawful act on its part in response to an act of aggression committed earlier by the imperialist state which led to the forcible enslavement of said people and the territory which it occupies. The people of a dependent or colonial country preserve the right to counter action to an imperialist aggression for the duration of the whole period of annexation of the given country or part of its territory. At any moment the oppressed people, living on the territory annexed by the imperialist state, have the right to launch a national-liberation struggle against this imperialist state. Such a struggle will be just and legitimate, since, in the first place, neither aggression nor annexation

${ }^{18}$ V. I. Lenin, Socinlism and War (The Attritude of the R.S.D.L.P. Towards the War) 15-x 6 (Foreign Languages Publishing House ed., 1952). Originally written in July-August, 1915. 
enjoy the benefits of a statute of limitations, and, in the second place, international law forbids aggression and consequent annexation puts them outside the law ${ }^{19}$

The implications of this contention are crystal clear. Stripped of jargon, what it all really amounts to saying is this: colonialism is an absolute evil, fathered by aggression and tainted by original sin that has never been expiated. Hence, every state possessing colonies ipso facto stands convicted of having perpetrated in the past an act of Hlagrant aggression and, as a corollary proposition, every subject people retains forever the right to repay this old crime against the law of nations with suitable reprisals aimed at enabling it to recover its former independence. Such action by an insurgent movement can never be qualified as an aggression, regardless of the specific circumstances surrounding its genesis and evolution, since the prior lawlessness of the imperial power which reduced the area to dependent status in the first place absolves it of any guilt. By that token, wars of national liberation represent, as an axiom, licit responses to sufficient provocation, defensive measures by their very nature. Conversely, resistance on the part of the imperial power to these lawful aspirations so as to preserve a status already rooted in a violation of international law is, by the same definition, offensive and aggressive. If the colonial régime persists in clinging to its former positions and uses arms to defend it illgotten privileges, it merely compounds the offense and adds a second crime to its tarnished record.

The errors and distortions inherent in this line of reasoning are too numerous to treat them all in detail. Only its more fundamental inaccuracies will be pointed out here. To begin with, such a projection of the rule of international law prohibiting aggression back through the ages is totally unwarranted. The notion of aggression as a breach of positive international law is of very recent vintage. It neither applies to earlier times in which different juridical values obtained, nor can it be reasonably so transposed to judge previous events by certain criteria in vogue today but alien to the historical context in which these incidents occurred. To do so is simply to play fast and loose with all commonly recognized standards of objective inquiry and, one may interject, also to behave in a thoroughly unMarxist fashion. Nonetheless, contemporary Soviet writers do not scruple to revise international law for the sake of ideological and political convenience. That the final results of this drastic re-write job have no scholarly merit bothers them not a whit. Nor is it probable that they will develop strong compunctions in the near future toward continuing to pursue this sort of game.

If all this were to remain on the plane of theory alone, it could simply be disregarded. Not so, however, for what at first blush may seem an academic exercise has had some disturbing practical consequences. In a series of recent test cases involving use of force or overt threat of use of force by newly emergent nations against European powers-e.g., India in the Goa dispute; Indonesia in the

\footnotetext{
${ }^{10}$ Sharmanazashvili, supra note 8 , at 60 .
} 
quarrel over West New Guinea-the main excuse given by the ex-colonies for resort to arms has faithfully echoed the theme struck by Moscow. Portugal in one instance, the Netherlands in the other (and there are more examples), all were now pronounced to be guilty of aggression and of having been guilty of aggression for centuries. Their very stay in the disputed territories was brought up as prima facie evidence of an aggressive past, proof of an unrepentant aggressive present, and tantamount to a promise of an equally aggressive future; to use military means against such sinners was not only permissible, but literally laudable, for not only did it serve to wipe away an ancient debt, so the thesis runs, it also upheld international law by punishing an obvious transgressor. What this has to do with the established legal order and how one can square it with known legal principles remains for some students of the current scene an incomprehensible enigma.

The next objection that comes to mind in connection with this question hinges on the fact that, historical veracity apart, the whole plaidoyer simply smacks of an enthusiastic espousal of the tribal rule of an eye for an eye, and a tooth for a tooth. One may counter that by pointing out that even if the original methods by which certain countries acquired colonies were very seldom simon pure, two wrongs have never yet made a right. One trouble with reprisals, as any cursory glance at the annals of diplomatic history will disclose, is that their use in a given situation merely leads to a steadily rising curve of mutual recriminations and a growing incidence of lawlessness, and that every time one party to a conflict takes liberties with the law under the pretext of avenging a wrong, the other discovers a ready reason to adopt a like course, and so on ad infinitum. The whole process leaves very little room for legal considerations and soon degenerates into a frantic race to see which side will bypass and circumvent the law faster and offer the more plausible rationalizations for its arbitrary conduct.

True, as mentioned before, in the midst of fighting a partial breakdown of the law, even that branch of the law specially devised for warlike conditions may very well be inevitable in any case. This has happened so often it seems almost a fixture of the international scene whenever peace gives place to armed hostilities. But this is still altogether different from coolly advocating such a dismantlement of the established jural fabric ahead of time; and there is something grossly contrived and frankly expedient about digging into the past for reasons to help excuse otherwise reprehensible plans one is harboring for the future.

The third, and last, comment on this score is that an approach of this genre again plainly puts the stamp of approval on adherence to a double standard in in. ternational law. Indeed, having thus been branded a past aggressor and virtually placed beyond the pale of the law, a colonial power is expected then meekly to submit to whatever treatment is meted out to it, without reacting, without pro. tecting its interests, without recourse to any remedy except, as it were, to take its medicine without a whimper. It cannot even take defensive measures, for, accord. 
ing to the present point of view, the national-liberation movement is presumed to be acting in self-defense and there can be no self-defense against self-defense.

So, while one party to the conflict apparently may, in line with this thesis, behave literally as it pleases, the other must do nothing. No matter what policy the one pursues, it is hailed as fully justified in the eyes of the law, whereas the other stands just as surely condemned for whatever it tries to accomplish on its own behalf, virtually an outlaw bereft of all legal protection or safeguards. How practicable any scheme of international relations predicated on such notion can be is best left to the imagination.

\section{III}

\section{Wars of National Liberation and the U.N. Charter}

\section{A. The Soviet View}

Not content with denouncing colonial wars and defending wars of national liberation on the above grounds, Soviet spokesmen have also appealed to the United Nations Charter in support of their stand. Ordinarily, the argumentation here revolves around one or more of the following propositions. In almost every case, the point of departure lies in the citation of those clauses of the Charter which refer to the principle of "equal rights and self-determination of peoples," mention the obligation of member-states endowed with colonial possessions to help the latter develop self-government and of those administering trust areas to promote the "progressive development" of their wards "towards self-government or independence." The very inclusion of these provisions in the Charter is always credited to the strenuous efforts of the U.S.S.R. in sponsoring these ideas at the San Francisco Conference and successfully urging their adoption on the rest of the participants. ${ }^{20}$

Having taken due note of the several articles in the Charter featuring such formulas, Communist authors then unanimously interpret the language of the document so as to equate self-determination and self-government with outright political independence as a separate state. While they concede that the concept of self-determination covers more ground than just political emancipation, they insist that it is imperative that it also include the right to sovereign self-rule. A given people need not, according to them, choose such a future for itself, but it must at least have the opportunity to decide that issue on its own. Likewise, though a few Soviet commentators admit that the drafters of the Charter intentionally distinguished between "self-government" and "independence," reserving the use of the second

${ }^{20}$ S. B. Krylov, I Materiazy K Istoril Organizatsi ObyedinennyKh Natsil (Materials on the History of the UnIted Nations) I58-67 (1949); id., Istoriya SozDaniYa Organizitsil ObyedinenNYkH Natsil, Razrabotka Ustava Organizatsil Obyedinennykh Natsil (History of the Creation of the United Nations, Drafting of the Charter of the United Nations 1944-I945) 156-172 (I960). See, too, Levin, Printsip samoopredeleniya natsii i likvidatsiva kolonializma (The Principle of the SelfDetermination of Nations and the Liquidation of Colonialism), [1962] Sovetskoe Gosudarstvo I Pravo, No. 8, at 92 . 
expression in conjunction with the régime of trust territories, ${ }^{21}$ all nevertheless completely reject the thought of self-government meaning anything inferior to independence. $^{22}$ To them-and, one should add, not to them alone ${ }^{23}$-genuine self-government logically leads to, and culminates in, total independence; and the whole process must not stop short of having reached this, its natural, objective.

Such a one-sided interpretation of the Charter is open, of course, to serious criticism. On the other hand, it must be acknowledged that there has been in recent years a consistent trend in neutralist circles and among newly emergent nations admitted into the United Nations to give these passages of the Charter precisely that reading. In this endeavor, one need hardly add, they always meet with the enthusiastic backing of the Soviet Union and its allies. And, while not free of weaknesses, this introductory part of Moscow's anti-colonialist brief still represents its most solid segment. From here onward, the quality of the reasoning steadily deteriorates.

However, let us assume for the sake of discussion that the testimonials to selfdetermination and self-government displayed in the Charter can both be reduced to the uni-dimensional idea of full-fledged independent status for the beneficiary nations. The next Soviet move is to proclaim that "the principle of self-determination of peoples is one of the most important principles of contemporary international law."24 That, together with the explicit endorsement conferred on it by the Charter, makes it doubly binding on the members of the Organization who thereby assume, so the thesis runs, a solemn legal obligation of first-rate magnitude to enhance its universal observance. For colonial powers this means doing everything possible to hasten the progression of their overseas holdings along the path to complete independence or, in any event, to free choice of their subsequent political destiny. The advance of the subject peoples to freedom, therefore, must unfold without interruptions, proceed at maximum speed, and have a minimum duration.

In fact, from an examination of the Soviet record in the United Nations and elsewhere, one gains the conviction that, in the last analysis, Moscow expects a state administering a colony or a trust area to set the latter at liberty at the first sign of a demand on the part of the local population that the mother-country relinquish the reins of authority. In other words, to pursue this exposition of the Charter's

\footnotetext{
${ }^{21}$ E.g., S. B. Krylov, I Materialy k Istori Organizatil Obyedinennyuh Natsil (Materials on the History OF THE UNITED NATIONS) $159 \mathrm{n} .8$ (I949).

${ }^{22}$ See, for example, G. I. Tunrin, Voprosy Teorir Mezhdunarodnogo Prava (Questions or the TheORY of International Law) 8 (I962); C. Berezowski, op. cit. supra note 4, at 47-48; Korovin, Mezhdunarodnoe pravo na souremennom etape (International Law at the Present Stage), 7 MezphuNARODNAYA ZHIZN 24 (r96I); Starushenko, Protiv izurashcheniya printsipa samoopredeleniya narodov $i$ natsii (Against the Distortion of the Principle of Self-Determination of Peoples and Nations), [1958] Sovetskoe Gosudarstvo i Pravo, No. I, at 63-66.

${ }^{28}$ Thus, A. Ross, Constitution of the Unitred Nations 185 (1950).

24 Baratashvili, Printsip samoopredeleniya narodov v Ustave OON (The Principle of Self-Deternination of Peoples in the U.N. Charter), in G. I. Tunkin (ED.), Voprosy Mezhdunarodnogo Prava (Quzstions of Internatronal LaW) (Uchenye Zapiski, Institut Mezhdunarodnyki OtNoshenii), vyp. 2, at 57 (1960).
} 
provisions, every state with non-self-governing possessions incurs a legal responsibility to prepare these for early independence and grant them this wish whenever they ask for it. This legal duty, it should be noted, is said to apply not only to the members of the United Nations, but to represent a universal rule valid for all states. The Charter, so the theory goes, only "affirmed" an already existing norm of general international law to that effect and, anyway, the Charter itself is now described as an authoritative statement of modern principles of international law for the entire world community. ${ }^{25}$

To this legal duty unilaterally imposed on states with dependencies corresponds the legal right of the United Nations, acting under the Charter and general international law, to demand due performance. However, this fills only half the picture, for the primary right in this sphere allegedly resides not in the Organization, but in the colonial peoples themselves. The rationale for reaching this conclusion again stems from the axiom that subject nations stand throughout as equal subjects of international law, and that their relations with the metropolitan authorities are therefore regulated by the precepts of international law, including the most important of all-the rule enunciating the right of peoples to self-determination. This last principle, then, obtains in full in the conditions of association of a subject people with the dominant country-with the result, it is claimed, that "the consummation by the colonial peoples of their right to self-determination ... [is] not the internal business of the home state, but . . . a question of international character."26 So, where the mother-country bears the duty to give effect to the principle of selfdetermination, its possessions hold the concurrent right to secure from it prompt and adequate fulfillment of its responsibilities on that score. Hence, the obligation which, according to Moscow, both the Charter and general international law recognize as vested in the imperial states to bring a quick end to colonialism within their domains does not constitute a voluntary expression of an abstract sense of duty or a unilateral donation bestowing a gift or a favor, but an enforceable reciprocal relationship in which the rights of one partner correspond to the duties of the other.

The construction is supremely important, for it means that when a colonial state fails to behave as prescribed in the matter of promoting the independence of the component parts of its empire it is deemed to have forthwith committed more

${ }^{25}$ In this case, the Soviet government chose to interpret the Charter as an agreement erga omnes, but on other occasions it has seen fit to defend the view that non-member states are not bound by the Charter. Presumably, it all depends on which clause is involved, on the general situation, and where Soviet interests of the moment lie.

${ }^{20}$ Baratashvili, supra note 24 , at 65 . The same theme is developed in G. B. Starushenko, op. cit. supra note 4; L. V. Speranskaya, Printsip Samoopredeleniya v Mezhdunarodnom Prave (The Principle of Self-Deternination in International Law) (I96r); Baratashvili, Za Svobodu i Nezavisimost Narodov (For the Freedom and Independece of Narions) (xg6o); Kozhokhin, Raspad kolonialnoi sistemy imperializma $i$ sovremennoe mezhdunarodnoe pravo (The Disintegration of the Colonial System of Imperialism and Contemporary International Law), Vestnik Leningradskogo Universiteta, No. 23, seriya ekonomiki, filosofii i prava, vyp. 4, at II6-24 (1958). 
than just an infraction of international law in principio or to have been caught in a breach of promise or an act of bad faith. Instead, it is taxed with a violation of the terms of a specific quasi-contractual undertaking toward a specific party. By the same token, the latter may now lawfully resort to appropriate reprisals to redress the wrongs thus inflicted upon it.

Soviet sources are unanimous on this last point. Any attempt to hinder a dependent area's aspiration toward political freedom ipso facto constitutes a flagrant infringement of the right to self-determination guaranteed under international law to all peoples, subject nations as well as communities organized as sovereign states. Accordingly, it is asserted, "any resistance to the free realization by the peoples of the right to self-determination represents a violation of the norms of international law-intervention in the domestic affairs of another nation." And, "armed intervention aimed at preventing a people from realizing the right to self-determination is aggression, that is, the gravest international crime." ${ }^{27}$

To sum it up, then, reluctance on the part of a metropolitan state to foster independence in its colonies or any manner of opposition on its side to a native freedom movement is eo ipso an offense against international law and the U.N. Charter. Should the home-country resist such a challenge to its rule by force of arms, it is again, by definition, guilty of naked aggression in the legal meaning of that term. In either case, the lesson drawn from the situation is that "the peoples of the colonies are fully entitled with arms in hand to seek liberation from the yoke of a colonial power evading a peaceful settlement of said question and be the first to start military action against it with the object of destroying its military forces stationed in these countries." 28 If these troops decide to fight back, the imperial government is guilty of yet another breach of the law of nations, for "the position of an imperialistic colonial state which by means of use of armed force attempts to keep a colony in its sphere of domination is contrary to the law."20

Sweeping as this may sound, the Soviet offensive against "colonialism" does not stop there, but rushes onward to even greater extremes. Up to here, the attack had followed the path of contending that any policy intended to perpetuate the disenfranchised status of the dependent territories or to impede their accession to full independence went counter to the principle of self-determination laid down by the Charter and recognized by international law. The next step takes the form of a denunciation in toto of colonialism per se as fundamentally incompatible with the spirit and the letter of today's world legal order, regardless of its

\footnotetext{
${ }^{27}$ Baratashvili, supra note 24, at 60; G. V. Sharmanazashyili, Pravo Mira (The LAw of Peacz) 7I76 (ig6r); id., Printsip Nenapadeniya v Mezhdunarodnom Prave (The Principle of Non-Aggression in International Law) 66-8I (1958); K. A. Baginyan, Narushenie Imperialisticheskimi Gosudarstvali Printsipa Nevmeshatelstva (The Violation bX the Imperialists States op the Principle of Non-Intervention) II0-20, I32-42 (I954); Piradov \& Starushenko, Printsip neumeshatelstua $v$ sovremennom mezhdunarodnom prave (The Principle of Non-Intervention in Contemporary International Law), Sovetskil Ezhegodnik Mezhdunarodnogo Prava 1958, at 249 (1959).

${ }^{28}$ Sharmanazashvili, supra note 8 , at 60 .

${ }^{20} \mathrm{Ibid}$.
} 
practical manifestations. Thus, even colonialism as a general phenomenon on the global scene, namely, in a historical conjuncture where it has not generated conflict, nevertheless now finds itself condemned as an offense against basic precepts of international law..$^{30} \mathrm{~A}$ similar argument has already been encountered earlier, resting on the proposition that all dependencies are established through an act of aggression and that the original sin of violence underlies every instance of colonial rule. The present theme eschews this line of reasoning (impossible to uphold in international law in any event), in favor of another approach, and focuses instead on the formula featured in article $x$, paragraph 2, of the U.N. Charter.

According to this clause, the purposes of the Organization include that of developing "friendly relations among nations based on respect for the principle of equal rights and self-determination of peoples, and to take other appropriate measures to strengthen universal peace." By juxtaposing the words "equal rights and self-determination of peoples" and "other appropriate measures to strengthen universal peace," Soviet jurists extrapolate from the language of the paragraph the thesis that respect for equal rights and self-determination of peoples represents a condition of universal peace. Conversely, failure to observe this rule in effect amounts to a threat to the peace or breach of the peace within the meaning of the Charter. Or, to phrase it differently, "the full and consistent implementation of the principle of equal rights and self-determination of peoples goes hand in hand with the maintenance of peace and international security."31

Colonialism, from Moscow's vantage-point, personifies the very negation of the idea of equal rights and self-determination. Hence, the very existence of colonies already marks that many concrete incidents of threats to peace which, in turn, can only be resolved through the total and immediate liquidation of every instance of colonial rule in conformity with the freely expressed will of the inhabitants of the interested subject areas. The prospect that any nation so consulted should elect to continue as another's subject is dismissed ex principio as an absolutely impossible contingency. But, in the meantime, and as long as a single case of colonialism survives anywhere on the face of the earth, universal peace remains in acute jeopardy, for, as Soviet spokesmen never tire of repeating, "violation of the principle of self-determination means violation of the principle of peaceful co-existence or the bases of the U.N. Charter itself."32 Since the

${ }^{80}$ N. V. Chernogolovrrin, Krushenie Kolonializma i Mezhounarodnoe Pravo (The Disintegration of Colonialism and INTERnational LAw) 26 ( $\left.\mathrm{Ig}_{3}\right)$ : "The colonial regimen is in flagrant contradiction with the Charter of the UNO. ..."

${ }^{82}$ Osnitskaya, The Downfall of Colonialism and International Law, I INTERNational AfFairs 39 (Mfoscow 196r). See, too, Bokor-Szegö, The Colonial Clause in International Treaties, 4 Acra Juridica Academiax Scientiarum Hungaricae 262 (1962); Lyubomudrova, Samoopredelenie natsii-odno is osnounykh uslovii mezhdunarodnogo sotrudnichestva $i$ mirnogo sosushchestvovaniya (The Self-Determination of Nations-One of the Basic Conditions of International Cooperation and Peaceful Coexistence), in S. B. Krylov \& V. N. Durdenevskil (Eds.), Mezhdunarodno-Pravovye Formy Mirnogo Sosushchestyovaniya Gosudarsty i Natsir (International Legal Forms for the Peaceful Coexistence of States and Nations) I6-58 (1957).

sa Tuzmukhamedov, supra note 9 , at 87 . 
key function of the United Nations consists precisely in maintaining and preserving world peace, colonialism is therefore seen as a blow at the very foundations on which the Organization rests. From that it takes but one short step to voice the companion slogan that, given the fact that it endangers peace merely by being there, "colonialism in any form is the worst crime against humanity." 33 And those responsible for it stand as morally convicted criminals before the bar of world opinion by virtue of their imperial status alone.

With such a perspective on the place and role of colonialism on the international arena, it comes as no surprise to find Soviet spokesmen and publicists alike vigorously advocating use of force to eradicate this unspeakable evil and to protect the legitimate interests of the victimized parties. Resort to violence to safeguard a lawful right so vital as self-determination is thereby elevated to the rank of an inherent attribute fully equal to that of individual and collective self-defense to which, let it be noted en passant, it is said to be closely related. Indeed, not only is such a course of action a legal right, it becomes tantamount to a legal obligation, an instrument for the redemption, even if somewhat belated, of international law. Or, as one Soviet source prefers to put it,

... refusal to oppressed peoples of the right to make use of national-liberation war as an extreme and temporary measure in response to the forcible attempt to hold them back in a position of colonial dependency and imperialistic oppression runs counter to established, universally recognized principles and norms of international law. With fire and sword the western powers seized and kept "their" colonies. But aggression and annexation cannot remain unpunished... . Refusal of the necessity of punishment for aggression and annexation means the recognition of lawlessness in international relations. $^{34}$

Furthermore, the right in question resides not only in the colonial nation directly affected by its adverse experience with colonial servitude; the United Nations is likewise vested with full authority to take appropriate action, including, if need be, collective sanctions to uphold respect for the right to self-determination and, coincidentally, to enhance peaceful co-existence. However, this does not exhaust all the possibilites envisaged in certain quarters. Occasionally, one also hears the added claim made, the most extreme of all to date, to the effect that "the refusal of the colonists to grant independence to a people or return to a state part of its national territory gives the Afro-Asian states the full right individually and collectively to resort to force." 35 If taken literally, this would be equivalent to pronouncing an anathema on any recalcitrant colonial power, proscribing it

${ }^{38}$ Id. at 89; Modzhoryan, Raspad kolonialnoi sistemy $i$ OON (The Disintegration of the Colonial System and the U.N.), Sovetskin Ezhegodnix Mezhdunarodnogo Prava 1960, at 125 (1961).

${ }^{34}$ Tuzmulhamedov, supra note 9, at 90. He adds (p. 9I): "National-liberation wars can be equated with one of the forms of international sanctions, the application of which on the basis of the UNO Charter is being demanded ever more insistently by the peoples toward colonial powers persisting in their illegal policy of barring the self-determination of dependent peoples."

${ }^{35}$ Id. at 88-89; V. K. Sobakin, Kollektivnaya Bezopasnost-GarantiYa Mirnogo Sosuscitestvovaniya (Collective Security-The Guarantee of Peacefur Coexistence) 409 (ig62). 
and branding it an outlaw, on which is declared an open season. A state so designated becomes fair game for all-primarily, of course, for those nations which, as former victims, enjoy precedence in exacting retribution.

Still, no logical reason exists for restricting the right to mount such a crusade against the hated "colonialists" to the ex-colonies alone, though it may seem more politic at the moment to phrase the idea that way. Otherwise, in the spirit of this scheme apparently anyone can take a hand and cover himself with glory as a champion of law and order and the rights of the weak and oppressed. Just as the pirates of old, the imperial powers are thus suddenly transformed into hostes humani generis, objects of universal opprobrium on whose head anyone can, indeed ought to, visit the dire punishment they so richly deserve.

\section{B. A Critique}

So many objections come to mind in looking over these statements of the Soviet position concerning the purported impact of the Charter on the phenomenon of colonialism that one hardly knows quite where to begin. First, it should perhaps be reiterated that, Soviet contentions to the contrary notwithstanding, self-government and self-determination have ordinarily not been understood as synonymous with state independence, and that in its insistence on equating them Moscow high-handedly disregards altogether the technical side of the question. Even Communist sources concede that the drafters of the Charter chose their words carefully and deliberately and that, on this occasion, they purposefully picked these different terms, fully aware of their non-identity.

To say that the language of the Charter has since undergone such interpretation that now this earlier distinction has evaporated does not resolve the issue, for this is not merely part and product of the common process of tacit revision of some elements of the Charter. It would be difficult to quarrel with the latter, since all so-called "living documents" go through the same experience. However, if and when an effort is made to represent the matter as though a given viewpoint, known to be of recent vintage, has really always held sway and to picture it as an absolute and long-established truth, contrary to all sense of history and spirit of objective inquiry, this is pushing it a bit too far. Even if what the Soviets maintain the Charter means with respect to self-determination has become perfectly respectable as of late in some circles, they cannot convincingly make that claim $a b$ aeterno.

Equally objectionable are many of the Soviet assertions concerning selfdetermination as a legal right. In taking that stand, they blithely ignore the fact that, from the moment of the concept's inception in its twentieth century Wilsonian garb, many of the world's leading jurisprudential minds have refused to recognize it as a principle of positive law at all. Even now one finds it described more often than not as "a programmatic policy statement," "a political formula," "a 
meta-juridical norm," in fact, anything but a legal prescript. ${ }^{30}$ The opposite opinion, too, of course, commands its quota of adherents; and the two camps are usually locked in a doctrinal dialogue. But, what sets non-Soviet champions of selfdetermination as a legal right apart from their Soviet colleagues is that the latter waste no time on debate, as though the possibility of an alternative conclusion simply did not exist. The answer is by no means quite that self-evident. By failing to discount the valid criticism which their thesis invites, instead passing it sub silentio, Soviet jurists badly weaken their stand rather than strengthening it, as is their hope.

-A further comment needs to be made in this connection. Let us again assume for the sake of argument that currently self-determination is indeed a formal legal right. That still leaves unresolved the question of its locus. As already mentioned, Moscow's view on this score is that the right legally rests with the colonial and dependent nations themselves, with the United Nations acting as an institutional guarantor of due performance. Such a contention fails to convince. The Charter, on which Soviet publicists rely so heavily to make this point, is not entirely clear. But it nonetheless manages to convey the impression that the right at stake here would enure to non-member, non-sovereign entities to which the text refers in this context not in the form of a right stricto sensu, but more in the capacity of an indirect benefit accruing to a third party by virtue of a specific agreement to that end between other contracting parties.

Likewise, the other United Nations materials which the Soviets have been so fond of citing in the past as upholding their thesis, notably the 1952 Resolution adopted by the General Assembly on "The Right of Peoples and Nations to SelfDetermination," are even more susceptible of this interpretation. They also address themselves exclusively to the states members of the Organization, exhorting them to give effect to the various recommendations in the dependent territories under their administration. In dealing with the right to self-determination, then, both the Charter and the sundry pre-Ig6o U.N. documents voted pursuant thereto may perhaps more accurately be described as functioning in a mode akin to that of pacta in favorem tertii. In this case, the evidence strongly favors the conclusion that the right/duty relationship applies in toto only as between the individual members of the United Nations and between each of them and the Organization as a distinct personality, while the colonies enjoy, for the purposes of this arrange-

${ }^{38}$ For some of the objections to the idea of self-determination as a right in positive international law, see Eagleton, Self-Determination in the United Nations, 47 As. J. INr'L L. 88 (1953); N. BENTwich \& A. Martin, a Commentary on the Charter of the United Nations 7, I43 (I951); L. Goodrich \& E. Hambro, Charter of the United Nations, Commentary and Documents 235 (1946); H. Kelsen, Thb law of the United Nations, A Critical Analysis of Its Fundamental Problems 50-5i (1950).

It should be noted that among Soviet scholars, too, the opinion has sometimes been expressed that self-determination was a political concept, but that the Charter elevated it into a legal norm. See, to that effect, Molodtsov, Raspad sistemy kolonializma i ego vliyanie na meshdunarodnoe pravo (The Disingtegration of the Colonialist System and its Infuence on International Laiv), [1956] SovetskoB Gosudarstvo I Pravo, No. 5, at 73, 8r. 
ment, the status of objects, passive recipients of privileges which others voluntarily choose to extend them.

As formulated above, the Soviet right/duty concept in conjunction with the Charter's pronouncements on self-determination cannot be sustained for yet another reason. In a relationship of this genre, rights and duties must be reciprocal, that is, both parties incur liabilities and gain assets, with one side of the ledger ordinarily neatly balanced against the other. However, the way Moscow approaches the issue, the situation between an imperial power and a colony is an entirely unilateral one-the metropolitan country carries all the debits, the colony owns all the rights, or, conversely, the former has no rights, only obligations, the latter has no duties, only rights. As a juridical construction, the scheme will not stand up to criticism. Again, it reminds one in its essentials of the conditions which obtain where two parties enter into an arrangement in favorem tertii.

In such a contingency, the right to self-determination would not properly amount to a right, and the companion duty to grant independence could not constitute a proper duty either. The Soviets will not accept this conclusion, but until they can make their own arguments more convincing, this line of reasoning will continue to find acceptance elsewhere.

The remaining propositions of this portion of the Soviet anti-colonial thesis can be disposed of quite brielly. The notion that colonialism as such is contrary to the U.N. Charter is, needless to say, impossible to substantiate. Otherwise, one can hardly explain how powerful states with vast colonial holdings who were among the chief drafters of the document would have welcomed an idea of this sort and freely subscribed to it. Likewise, the thought that several states endowed with colonial possessions would, on their own, embrace an agreement which, to all intents and purposes, vilified them as criminals in the eyes of the international community sounds well-nigh incredible. No one simply looked at colonialism that way when the San Francisco Conference met. Were it otherwise, the Charter would have been worded altogether differently, given the power alignment in those days.

As for the proposition that in the cause of promoting self-determination resort to force is thoroughly legitimate, just as it would be in the exercise of the innate national right of individual and collective self-defense, to urge it is to perpetrate a reductio ad absurdum. For the Charter is explicit on this score and restricts resort to armed violence on the international level to self-defense against overt attack alone and, even so, always subject to the Organization's ultimate approval. To say that a select group of states, picked on the basis of their colonial past, holds the right at any time and by its own choice to rely on force against an imperial nation in order to "liberate" the latter's dependencies is to conspire against the very raison d'être of the United Nations and the sundry procedural safeguards devised to ensure its effectiveness as a bulwark of peace.

If the United Nations is to mean anything, it can tolerate no differential standards 
for judging cases of outbreaks of international violence; and violence by ex-colonies against imperial nations is qualitatively indistinguishable from any other type of violence and therefore prohibited. To have the newly emergent nations enjoy privileges on this account that are forbidden to others would be tantamount to announcing officially that, though all the members of the United Nations are equally bound by the Charter, some are a little less so than others. By that token, the chosen few would be allowed to invoke the special prerogative of employing armed force with regard to a certain category of nations, while all other members would be required strictly to adhere to the general rule prescribing peaceful methods for settling disputes. The damage such discriminatory practice could cause to the image and authority of the United Nations is incalculable, probably irreparable, for this would come close to destroying the Organization as a meaningful instrument for world peace.

Furthermore, once these gradations of preferential status are introduced, who is to say that similar privileged treatment would not later be extended to various other groups of states chosen on the strength of yet other criteria, but always to the detriment of some segment of the Organization's membership? Indeed, there need be no logical end to the distribution of these extraordinary dispensations; and a single breach in this crucial sector is likely to bring about the early collapse of the rest of the elaborate machinery of the United Nations designed to forestall precisely this contingency. In any form of human association, use of an avowedly double standard to pass on the behavior of the participants commonly leads to mayhem in the end. On the international scene, with relations as tense as they are today and the balance of power so delicately poised, it would result in nothing less than chaos compounded.

\section{IV}

\section{The "Just WAR" Theory}

The final chapter of the Soviet brief in defense of wars of national liberation is based on the idea of "just war." Though frequently encountered in Soviet literature today, that concept emerged only relatively recently as a recognized ingredient of the Marxist ideology. In effect, both Marx and Engels paid very little attention to the matter of qualifying wars which occurred in their lifetimes as just or unjust (there was, of course, no question as yet of branding armed conflicts as legal or illegal). When they did feel called upon to comment on some outbreak of hostilities between states, which happened on several occasions, they chose instead to treat the issue in terms of their own dichotomy of "progressive" versus "reactionary" wars. Under "progressive," they put all military hostilities which served to further the advance of the materialist course of history, as blueprinted by themselves; and under "reactionary," they grouped all uses of international coercion which they considered wishful attempts to stop or turn back the clock of history and therefore hopelessly foredoomed to ultimate failure. 
True, the expression "just cause," applied to such situations, is sometimes featured in their voluminous writings, but it adds no new dimensions to their analysis of the events and leads to no special conclusions. Rather, the idea of "justice" in this context appears throughout in a strictly subordinate role, as a quality incidental to the notion of "progress" and a derivative product of the latter: What is historically "progressive" is automatically also "just."

This mode of thinking is characteristic, too, of Lenin's pronouncements in which every political item, be it domestic or international, is assessed exclusively on the plane of whether it promotes or hinders the revolutionary program. As a practical politician, Lenin grasped better than Marx or Engels, the abstract theoreticians, the appeal of "justice" as a popular political slogan and so exploited it commensurately. But even then, it remained in his hands a weapon of very secondary importance. So far as he also was concerned, "justice" represented a mere handmaiden of "revolutionary progress" and never amounted to an autono. mous doctrinal element.

Today, when it is fashionable in the U.S.S.R. to denigrate Stalin and attribute almost everything worthwhile to Lenin's genius, the claim is made that it is Lenin who, "taking into account the new historical situation and the new tasks of the working class in the struggle for socialism . . . developed the Marxist definition of the character of war of the pre-monopolistic period, advancing the general moral-political principle of justice and injustice." And, according to these same sources, "this principle applies to the evaluation of all wars, but has an especially great importance for the analysis of wars of the modern era." ${ }^{37}$ Actually, this is quite a fanciful interpretation of the record, for it is under Stalin, and not Lenin, that the maxim of just wars fully came to the fore. Indeed, the very definition of just wars quoted at the outset derives from a publication the authorship of which was officially credited to Stalin and where is also offered a definition of unjust wars as "wars of conquest, waged to conquer and enslave foreign countries and foreign nations." 38

With Stalin's ascendancy, drawing a distinction between just or unjust wars

${ }^{87}$ Khomenko, in MArRsizM-LenimizM o VoINe I ARMII (MARXISM-LENINISM ON WAR AND ARMIES) 80 (2d ed. I96r).

${ }^{88}$ History of the Commonist Party of the SOViet Union (Bolsheviks) i68.

For Western analysis and critique of the Communist theories of just and unjust wars and interventions, see T. A. Taracouzio, The Soviet Union and International Law 31I-I5 (1935); Luis Garcia Arias, La Guerra Moderna y la Organizacion Internacional 213-3I (1962); I. Lapenna, Conceptions Soviétiques de Droit International Public 236-42 (1954); J. Y. Calvez, Droit International et Souverainete en U.R.S.S. 68-72 (I953); H. Kelsen, The Communist Theory of Law 149, 167 (1955).

For some recent Soviet studies on the question of just and unjust wars, see, in particular, Pukhovskii, Voiny spravedlivye $i$ nespravedlivye (Just and Unjust Wars), in MARrsizm-Leninizm o VoIne, ARMir I Voennoi Nauke, Sbornix Statel (Marxism-Leninism on War, Armies, and Military Science; ColLECTION OF ARTICLES) 34-43 (I955); Kurbatov, Marksizm-leninizm o voinakh spravedlivykh $i$ nespravedlivykh (Marxism-Leninism on Just and Unjust Wars), 12 Propaganda I Agrtatsiya 42-49 (195I); Chuvikov, Uchenie Lenina-Stalina o voinakh spravedlivykh $i$ nespravedlivykh (The Teachings of Lenin and Stalin on Just and Unjust Wars), 7-8 BoLsHevik I4-26 (x945). 
became common Soviet practice. The operative criteria always remained purely subjective, predicated on Moscow's assessment of the events from an ideological point of view alone, in turn reflecting, of course, the U.S.S.R.'s current diplomatic interests as well. Though unilateral in application and highly personal in conception, these standards were, nonetheless, unhesitatingly applied by the Kremlin to render judgment on various conflicts between states which happened to disturb the international scene. What is more, the invocation of this "moral-political principle" implied definite juridical consequences.

As far back as 1939, for instance, Stalin himself had publicly declared that "we stand for the support of nations which are the victims of aggression and are fighting for the independence of their country."39 The U.S.S.R. was, at the time, still a member of the League of Nations and officially a champion of its collective security system. In these circumstances, this would be an orthodox policy statement. Yet, it should be noted, Stalin made no reference whatever to the League, all but moribund by then in any case. Furthermore, in Soviet circles his dictum was thereafter treated as an enunciation of a general rule, not dependent on participation in any particular international organization. Thus, according to Soviet legal commentators, the formula simply affirmed that, ex principio, "there cannot be a similar relationship with the aggressor and the victim of aggression" and "this means that a state waging a just war must receive assistance and aid. ..."

Following the German invasion of Russia, the Second World War assumed, in Soviet parlance, the character of a supremely just war. In spite of this designation, however, Moscow did not, in the midst of the fighting, choose to indulge in any wholesale revision or repudiation of the established laws of war and, throughout, insistently demanded that the enemy likewise abide by the letter and spirit of the customary and conventional regulations on modern warfare. Significantly, the only marked departure from the old norms for which the Soviet régime admitted responsibility during the hostilities and which its jurisconsults openly tried to justify concerned rules setting conditions for the conduct of guerrilla warfare. ${ }^{41}$ Even so, the pleadings here rested on technical grounds and pursued their objective ostensibly within the frame of reference of established international law.

As soon as war came to an end, however, the Kremlin's erstwhile caution in handling this sensitive issue suddenly evaporated. Instead, Soviet jurists now rhetorically asked ". . . can we confine a sacred people's war against an aggressor and enslaver, a heroic struggle of millions of people for their country's independence, for its national culture, for its right to exist, can we confine this war within

${ }^{30} \mathrm{~J}$. V. Stalin, Report on the Work of the Central, Committee to the Eighteenth Congress of the CoMmunist Party of the Soviet Union (Bolsheviks) 15 (1939).

${ }^{10}$ E. A. Korovin (ED.), op. cit. supra note 3, at 557 . (Emphasis added.)

"See, in particular, the thesis developed by E. A. Konovin, Kratkn Kuns Mezudunarodnogo Prava, Chast II: Pravo Voiny (Brief Course on International Law, Part II: The Law of War) 34-36, 78-79 (1944). 
the strict bounds of the Hague rules, which were calculated for wars of a different type and for a totally different international situation?"42 They forthwith answered their own query in the negative. In the same vein, though some Soviet lawyers still tried to argue their case for the legality of guerrilla warfare in legal terms, they, too, soon fell back on the technique of appealing to the "justice" of their cause. By that token, "popular guerrilla warfare in the rear of an aggressor-a warfare which will be supported by all freedom-loving peoples" enjoyed "the protection of international law," but "vice versa, if the inspirer and defender of aggressive war, that is, unjust war, tries to use guerrilla methods of warfare, then such 'guerrillas' cannot be under the protection of international law."43

Subsequently, the pendulum swung even further in this direction. Things finally reached a point where Soviet publicists denounced outright all attempts to deal with the subject on accepted legal terms and flatly condemned all earlier efforts by their own compatriots to furnish a jural rationale for the changes that the régime had effected in the course of the late war in the stipulations of the Hague accords regarding guerrilla warfare. All these endeavors were now brushed aside on the grounds that their badly misguided authors had erroneously "analyzed the problems of partisan war without bearing in mind the LeninistStalinist teachings concerning just and unjust wars. ..."Henceforth, ran the injunction, "the task of the Soviet lawyers consists in giving a learned justification of the legality of partisan wars on territories occupied by the imperialist aggressors, keeping in mind the Leninist-Stalinist teachings on just and unjust wars." ${ }^{34}$ This task would take as its keynote the central theme that "in a war of liberation every person who takes up arms to fight against an aggressor fulfills a high patriotic duty, and his actions may not be regarded as criminal."45

The net effect of such an outlook would again amount to conferring total immunity on the party said to be waging a just war, irrespective of its actual behavior

'a Korovin, The Second World War and International Law, 40 AM. J. INT'L L. 753 (1946).

13 Trainin, Questions of Guerrilla Warfare in the Law of War, 40 AM. J. INr'L L. 56I-62 (I946); YuRIDIchesKII Slovar, op. cit. supra note 15, at 440; P. I. KudRYAvisEV (ED.), op. cit. supra note 15, at ror.

"Mankovskii, in [1950] Sovetskoe Gosudarstvo I Pravo, No. 7, at 69-7I; F. I. Kozhevnikov, Velikaya Otechestvennaya Volna Sovetskogo Soyuza i Negotorye Voprosy Mezedunarodnogo Prava (The Great Patriotic War of the Soviet Union and Sosie Questions of Internationai Law) $95-99$ (I954).

A curious discrepancy occurs in Soviet literature on the question of "partisan" war which deserves to be noted briefly. Soviet sources have always claimed that guerrilla warfare was legal under international law, but YuRIDicheskir SLovar, Op. cit. supra note 15, at 440, features a statement to the effect that "by virtue of this stipulation [Art. 4, para. 2], the Geneva conventions of 1949 establish the legality of a partisan movement on occupied territory, which was not foreseen in the Ig07 conventions." This lapsus calami is corrected in the second edition of the work, P. I. Kudryavrsev (Ed.), op. cit. supra note 15, at 102, where it is said instead that "by virtue of this stipulation, the Geneva conventions of I949 confirm the legality of a partisan movement on occupied territory."

${ }^{2}$ L. Oppenheim, Mezfiunarodnoe Pravo (Internationai Law) (6th ed, i949, by H. Lauterpacht; tr. by Ya. I. Retsker \& A. A. Santalov; ed. by S. A. Golunskii, Vol. II, Part I), editorial note on p. 235. Sec, also Modzhoryan, Partizanskie otryady i vooruzhennye vystupleniya mass $v$ period vtoroi mirovoi voiny (Guerrilla Units and Armed Action of the Masses in the Period of the Second World War $)$, id. at $282-86$. 
on the battlefield and behind the front-to giving it carte blanche to act as it wishes, while sentencing its opponent to suffer every indignity without recourse. And, it should be stressed, the bulk of these extreme pronouncements were heard well after the signature of the Geneva conventions of 1949, which the Soviets so often cite. There, a partial attempt was made to resolve the legal status of the irregular troops by putting them on equal footing, for certain purposes, with the regular armed forces. Such a venture, in turn, can realistically be expected to achieve success only if the guerrilla units, too, observe the established laws of war. The logic of the situation, however, seems to have escaped the Soviets who, instead, altogether absolve one side from any obligation whatever to respect the regulations and concurrently insist that the other side must nevertheless fully conform to the rules.

To want to punish an aggressor may be a laudible sentiment and one that deserves sympathy, but to do so by completely ignoring the laws of war, even if the wrongdoer is already guilty of that offense, can only make matters worse. To adopt, a priori, such an attitude when there is an outside chance that the so-called aggressor might after all mind the usual amenities is heedlessly, and needlessly, to precipitate the conflict into a lawless butchery.

The fact that Soviet legal experts focused primarily on issues of guerrilla warfare is crucial for the present discussion, for Soviet commentators are always quick to point out that, "where the imperialists attempt by force of arms to suppress the national-liberation struggle, the peoples rise in revolt which grows into national-liberation wars that customarily take on the form of a partisan struggle." And guerilla wars are, by definition, people's wars par excellence, hence "these are sacred wars." ${ }^{\text {"46 }}$ As such, goes the inference, they stand above the petty limitations of routine law.

It would serve no good purpose to dwell at greater length on the detailed vagaries of the Soviet campaign in praise of "just" wars. Anything so subjective and, one may add, so contingent on political whim, simply does not lend itself to meaningful analysis. Suffice it to note than the very concept itself runs diametrically counter to the spirit and the substance of the basic principles on which the post-war legal order was erected. In effect, one of the key concerns of the drafters of the Charter lay precisely in foreclosing the possibility of unilateral appeal by states to some ill-defined, abstract so-called "higher principles" to circumvent the text's express ban against recourse to violence in the international sphere. They deliberately avoided using the word "war" so as to preclude the usual abuse of that term, and even eschewed all reference to bellum legitimum or illicitum, to say nothing of bellum justum or injustum. In short, the chief object of the Charter was henceforth to bar resort to force-plain force-in interstate relations; and its language clearly reflects that preoccupation.

'6homenko, supra note 47, at 106. 
Yet, in spite of its loudly professed respect for the Charter's principles, Moscow continues to cling to an anarchistic device which the rest of the world has repudiated as fundamentally incompatible with its hopes for peace and security as embodied in the United Nations Organization. Nor, it should be emphasized, does the slogan of "just" war represent a weapon in the Kremlin's armory which it will wield only when the United Nations has failed to speak its mind when confronted with an outbreak of armed hostilities and its members must fall back on general international law. For the Soviet government has made it abundantly evident that, in proper circumstances, it will not hesitate to invoke these vague "higher values" to thwart even a decision of the United Nations with which it happens to disagree.

The Korean incident offers an excellent case in point. When, on that occasion, Vishinsky exhausted his store of legal excuses for the presence of the Chinese "volunteers" on the battle-front, he finally came up with that time-honored plea of all lawyers and statesmen who find themselves pressed for good arguments, namely, an appeal to indeterminate moral justifications, and solemnly declared: "The statement of the Ministry of Foreign Affairs of the People's Republic of China of November II, [1950] to the effect that the Chinese people's voluntary aid to Korea and their resistance to United States aggression had a moral foundation, was fully justified."

For that matter, the scope of the privileged status that Moscow claims for "just" wars in this respect can perhaps be gauged even better if one remembers that while those fighting for the right cause need not, according to Soviet authors, feel hamstrung by any undue consideration for legal technicalities, the United Nations itself cannot aspire to a like privilege and suspend the operation of the conventional rules. An exception might be allowed if the Organization is engaged in repelling and punishing an aggressor, so designated by unanimous vote of the permanent members of the Security Council supported by the required majority. However, in the latter instance, such liberty would probably be permissible again only because there could be no doubt that the United Nations' stand was "just," the U.S.S.R. having concurred in the collective action.

Otherwise, the Soviet view is that the United Nations must abide by the standard regulations. Thus, to cite once more the Korean experience, all Soviet spokesmen during that crisis insisted that the Hague rules continued to obtain; that the members of the United Nations remained bound thereby in toto; and that, furthermore, the Security Council could not on its own free the member states of the duties incumbent upon them by reason of these conventions. As an Austrian author generally sympathetic to the Soviet point of view put it in an article that appeared in the chief Soviet legal periodical, "the customs and laws of war are not mentioned

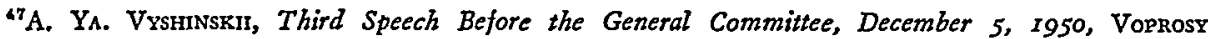
Mezhdunarodnogo Prava i Mezhounarodnor Politiki (Questions of International Law and INternational Politics 325 (I952).
} 
in the Charter, as it only regulates part of the international legal relations of states, members and non-members alike." Therefore, "the Charter assumed that commonly recognized law is still in force," and no U.N. organ can contravene it by deciding ad hoc to set aside temporarily these well established norms, the stipulations of the various Hague accords, inter alia, since these documents function "at present as a universal expression of the customary law of war obligatory for all states. . ." ${ }^{\$ 8}$ Besides, it was argued, even the Security Council is technically incapable of such action because "the decisions of the Security Council $\therefore$. do not have the force of juridical precedent and, consequently, cannot creatc general norms of international law"49 nor, apparently, supersede existing general norms.

Though urged as universally valid principles, these propositions obviously reflected the fact that the U.S.S.R. had not given its sanction to the United Nations' initial decision to intervene in Korea and refused to acknowledge the legality of the subsequent measures adopted by the General Assembly on this question as a usurpation of the functions of the Security Council. Nevertheless, the example does demonstrate that for a war to be "just," the Soviet leadership must pronounce it so; and that without its consenting vote, no other power on earth can achieve that result, not even the United Nations.

\section{$\mathrm{V}$ \\ "Just Wars" and Peaceful Coexistence}

One need not further belabor the point that Soviet espousal of the notion of "just" war cannot be reconciled with the aims of the United Nations Organization as stated in its Charter. What also deserves to be noted, however, is that the concept of "just" war cannot honestly be brought into harmony with the current Soviet campaign on behalf of "peaceful co-existence," either." Indeed, even "peaceful co-existence," the virtues of which the Kremlin so assiduously sings today and which it endlessly extols as a key to a better world, does not stand exempt from the basic reservation that it must give precedence to "just" wars, a superior instrument for "progress" in the dialectical scheme of history, if the interests of the two should collide.

First, then, "peaceful co-existence" must defer to "proletarian internationalism," since, as one Soviet source has frankly admitted,

While the principle of peaceful co-existence is designed for the historical phase of simultaneous existence on the international arena of two opposing systems, the principle

${ }^{48}$ Brandweiner, Amerikanskoe tolkovanie mezhdunarodnogo prava-uyrazhenie mezhdunarodnogo bezzakoniya (The American Interpretation of International Law-An Expression of International Latulessness), [1954] Sovetskoe Gosudarstvo I Pravo, No. 6, at 46-47.

${ }^{20}$ Levin, Falsifikatsiya ponyatiya mezhdunarodnogo prava burzhuaznoi lzhenaukoi (Falsification of the Concept of International Law by Bourgeois Pseudo-Science), [1952] Soversko: Gosudansrvo I Pravo, No. 4, at 57 .

${ }^{50}$ For an excellent survey and analysis of recent Soviet views on so-called co-existence, sec McWhinncy, "Peaceful Co-Existence" and Soviet-Western International Law, 56 AM. J. INr'L L. 95I-970 (1962). 
of proletarian internationalism is designed for a more lasting epoch, for, as V. I. Lenin indicated, national and state differences between peoples and countries "will yet persist a very, very long time, even after the realization of the dictatorship of the proletariat on a world-wide scale. . .."51

Next, "peaceful co-existence" must likewise make way for "solidarity with the oppressed peoples' struggle for national liberation." For all Soviet spokesmen, from Khrushchev on down, make no secret of where their sympathies lie, publicly declaring that "... . we are against imperialistic, colonialistic and, in general, against all wars, except those wars which peoples wage in fighting for their own liberation. These are sacred popular wars against slavery, against colonial regimes." "52 By the same token, oppressed nations can, they are continuously assured, count on the ready backing of the Soviet Union and its allies in their struggle for independence. Yet the latter still always insist that the support they willingly render to such "anti-colonialist" causes in no way detracts from their fervent desire for international peace. On the contrary, they maintain,

The socialist countries and the Communists all over the world will continue to aid and support the peoples who are waging an armed struggle against colonialism. Far from contradicting the concept of peaceful coexistence, this is an affirmation of that concept, since the issue at stake is respect for one of the basic principles of peaceful coexistencethe right of all peoples to order their own life as they see fit, to be masters in their own house. 53

In what shape these deft exercises in dialectical casuistry leave "peaceful coexistence" may well be imagined. As a Western student of Soviet affairs has rightly remarked, "If peaceful co-existence is to be a reality ... the concept of 'just' intervention or war will have to be put aside." Un Until that is done, "peaceful co-existence" will remain a myth. Granted, convinced Communists are certain that Marxist ideology furnishes them with a sure guide to the future and that in defending "just" wars they are simply facilitating the march of progress. By the same logic, however, those who do not share their beliefs may credit themselves with like ideals. The door will then again stand wide open for every government and every political movement to appeal to heaven, figuratively speaking, and, firmly bearing aloft a banner incribed with an appropriately inspirational message, be it "Gott mit Uns" or "Dialectical Historical Materialism is on Our Side," proceed to spread by the sword the advantages of its superior culture and fulfill its civilizing mission among its benighted neighbors.

\footnotetext{
s1 M. Airapetyan \& P. Kabanov, Leninskie Printsipy Vneshinei Polittri Sovetskogo Gosudarstva (Leninist Principles of the Foreign Policy of the Soviet State) 65 (1957), referring to $3 \mathrm{I}$ V. I. LENIN, SOCHINENIYA (WORKS) 72.

${ }^{83}$ N. S. Khrushchev, I Kommunizm-Mir I Schastie Narodov (Communism-Peace and Happiness OF PEOPLes) 379 (1962).

${ }^{63}$ Ponomaryov, Some Problems of the Revolutionary Movement, I2 WorLd MARXIST Review I3 (1962).

"‘ Hazard, Codifying Peaceful Co-Existence, 55 AM. J. INT'L L. II8 (196I).
} 
If the proletariat reserves for itself the right to liberate its fellow-workers from the yoke of capitalism, and newly independent nations feel destined to bring freedom to the still extant colonies from their imperial masters, the bourgeoisie could also assert the right to rally to the rescue of its class brethren imperiled by Communist revolutions and wars of national liberation. Unless one is blindly committed to an ideological code, objective observers must concede that if one party may excuse its otherwise unjustifiable behavior by invoking some abstract and totally subjective "sense of justice," all may do so. And overnight, the world will be back where it was fifty years ago; and the United Nations will be as dead as the League was towards the end of its ill-starred career.

\section{OuTrook}

The above sums up the Soviet position on the question of national-liberation wars and their status under present international law. This much remains to be said: there is no doubt that, today, the Soviets are successfully riding the crest of a popular wave of anti-colonialism-so much so that many of the slogans mouthed by Moscow, no matter how extreme, have as of late attracted a ready audience and in some quarters have come to be accepted as gospel truth. The annals of the United Nations, the General Assembly in particular, since the flood-like influx of new African and Asian states to its membership, will testify to that. In this connection, the Ig6o session, with its General Assembly Resolution entitled "Declaration on the granting of independence to colonial countries and peoples," marks a watershed.

True, that document, as finally adopted, was not the original Soviet draft, but a compromise text sponsored by a large group of Afro-Asian states. However, as Soviet sources are quick to point out, the latter "included nearly all the most important propositions advanced by the Soviet government." General Assembly officially went on record as a champion of many of the most radical principles of the anti-colonialist thesis long expounded by the Kremlin which, in the past, had brought down on the head of the Soviet régime a storm of criticism ranging from charges of sheer irresponsibility to accusations of flagrant disregard for international law and the letter of the Charter.

Yet, by overwhelming vote, the General Assembly has now vindicated Moscow's stand, in all its essentials. In sweeping language, it, in turn, declared that:

r. The subjection of peoples to alien subjugation, domination and exploitation constitutes a denial of fundamental rights, is contrary to the Charter of the United Nations, and is an impediment to the promotion of world peace and co-operation.

2. All peoples have the right to self-determination; by virtue of that right they freely determine their political status and freely pursue their economic, social and cultural development.

${ }^{25}$ Resolution 15i4(XV), Resolutions Adopted by the General Assembly During ITs 15 Th Session, Vol. I, Supplement No. I6 (A/4684), at 66 (1961).

${ }^{50}$ Chernogolovkrn, op. cit. supra note 30, at 25 . 
3. Inadequacy of political, economic, social or educational preparedness should never serve as a pretext for delaying independence.

4. All armed action or repressive measures of all kinds directed against independent peoples shall cease in order to enable them to exercise peacefully and freely their right to complete independence, and the integrity of their national territory shall be respected.

5. Immediate steps shall be taken, in Trust and Non-Self-Governing Territories or all other territories which have not yet attained independence, to transfer all powers to the peoples of those territories, without any conditions or reservations, in accordance with their freely expressed will and desire, without any distinction as to race, creed or colour, in order to enable them to enjoy complete independence and freedom.

6. Any attempt aimed at the partial or total disruption of the national unity and the territorial integrity of a country is incompatible with the purposes of the Charter of the United Nations.

7. All States shall observe faithfully and strictly the provisions of the Charter of the United Nations, the Universal Declaration of Human Rights and the present Declaration on the basis of equality, non-interference in the internal affairs of all states, and respect for the sovereign rights of all peoples and their territorial integrity.

Of course, technically, this General Assembly Resolution is no more than a recommendation and does not create a formal legal obligation. ${ }^{57}$ As an authoritative and prestigious statement of world sentiment, however, its weight and impact are undeniable. There is thus much truth in the comment of a Polish jurist to the effect that, if "the collapse of the colonial system is, next to the emergence of the world system of socialist states, one of the most important social phenomena of our epoch," then the "I5th session [of the U.N.] . . . represents, in this connection, a decisive turning-point" and its Declaration "is one of the most important documents in the history of the U.N.O."58 Indeed, what the resolution has done was morally to condemn colonialism in every shape and form, and to denounce all its practitioners ex principio. Legally, it could accomplish no more, but it went just as far as it could.

On the other hand, what the practical consequences of the declaration will be, no one can tell, except that they are quite likely to be nil. Extreme policies which

${ }^{77}$ Soviet authors take the same view. See, for instance, Starushenko, supra note 22, at 70, where the author writes that the resolutions of the General Assembly are not directives, but that their moral weight is nonetheless very great.

On the other hand, Modzhoryan, Raspad kolonialnoi sistemy imperializma $i$ nekotorye voprosy mezhdunarodnogo prava (The Collapse of the Colonial System of Imperialism and Some Questions of International Law), Soverskir Ezhegodnir Mezhdunarodnogo Prava 196r, at 37-38 (1962), claims that: "As distinct from the other resolutions of the General Assembly, the resolution of December I4, 1960, has not only great moral authority, but also legal force. Resolutions of the UNO General Assembly, 'adopted in accordance with the provisions of the UNO Charter, play an important role in the process of formation of new principles and norms of international law,' but in the instant case the reverse phenomenon took place: the resolution of December 14,1960 , confirmed a principle already widely enforced in international practice. For recognition of the illegality of colonialism even before the adoption of the resolution had become a norm of behavior for the socialist states, as well as for the young national states from the very day of their inception." The quote within the quote is from Tunkin, op. cit. supra note 3 , at $\mathrm{r}_{3}$.

${ }^{8}$ Antonowicz, La Déclaration de l'ON.U. sur l'Octroi de l'Indépendance aux Pays et aux Peuples Coloniaux, Annuaire Polonais Des Affaires Internationales 1962, at 24-30 (I962). 
overlook the hard facts of life and, as here, attempt to settle a difficult problem by advocating a unilateral and inequitable, therefore unrealistic, solution, usually fail where a more moderate approach might have succeeded. In any event, it is improbable that a measure which, a priori, places all the onus of guilt on one party to a contested issue and acquits the other of all responsibility, will play a very constructive role in human affairs.

Finally, it should perhaps be noted that the spirit of the 1960 General Assembly Declaration seems greatly inferior in its understanding of and respect for the goals of international law when compared to the doctrinal superstructure erected earlier by the "imperialist" powers to justify their expansionist policies which it condemns. The latter simply denied the applicability of international law to their dealings with colonial peoples. These lay outside the proper province of international law; and no pretense was made that its rules in any way extended to the business of building empires. International law was absolutely irrelevant in this context. Neither side could seek comfort in its provisions. Today's anticolonialist forces are infinitely less honest in their attitude, for they attempt to accomplish their ends within the framework of international law by abusing it for their own purpose. They demand the full protection of international law for the side they favor, yet completely deny the same protection to the one they oppose. This is but a travesty of law; and it would be far better simply to leave law out of it altogether and settle the issue as once before without reference to legal principles instead of playing fast and loose with the law, openly preaching a double standard of public conduct and, in the process, generally discrediting both the law and the United Nations that is supposed to preserve it. In our troubled times, the foothold maintained by international law in the daily repertoire of statc diplomatic practice is precarious enough without imposing this added strain on its already slender resources. 